\title{
Rethinking Municipal Markets (Bandabuliya) within the Context of Sustainability: Case of Cyprus
}

\author{
Damla Misirlısoy \\ Faculty of Architecture, European University of Lefke, Gemikonağı, Lefke, Mersin 10 Turkey, Northern Cyprus
}

Received February 25, 2021; Revised April 14, 2021; Accepted May 11, 2021

\section{Cite This Paper in the following Citation Styles}

(a): [1] Damla Misirlisoy, "Rethinking Municipal Markets (Bandabuliya) within the Context of Sustainability: Case of Cyprus," Civil Engineering and Architecture, Vol. 9, No. 3, pp. 883 - 891, 2021. DOI: 10.13189/cea.2021.090330.

(b): Damla Misirlisoy (2021). Rethinking Municipal Markets (Bandabuliya) within the Context of Sustainability: Case of Cyprus. Civil Engineering and Architecture, 9(3), 883 - 891. DOI: 10.13189/cea.2021.090330.

Copyright $\bigcirc 2021$ by authors, all rights reserved. Authors agree that this article remains permanently open access under the terms of the Creative Commons Attribution License 4.0 International License

\begin{abstract}
Municipal markets have played an important role in social, cultural and economic activities of the communities. Municipal markets can be seen as a symbol of tradition and as part of a city's tangible and intangible heritage. Municipal markets are part of the cultural heritage of their related community and therefore they must be conserved and continuity should be provided for future generations. For sustainable use of municipal markets, they should answer the needs of today's community by preserving their authenticity. The aim of the study is to identify municipal markets in Cyprus and propose sustainable adaptive reuse strategies for their future use. The study includes a holistic approach since municipal markets from North and South part of the island is observed through site survey. The research is also emphasized the significance of municipal markets as a part of Cypriot culture. As the method of the study, the model for achieving sustainable adaptive reuse of traditional marketplaces is used for developing strategies for the future use of the municipal markets. The results of the research address that the municipal markets are important for the cultural heritage of the related community. However, in Cyprus they used more for the economic activities, and important social and cultural values were ignored. Municipal markets should be conserved by considering the tangible and intangible heritage values. Local needs, beliefs, practice and traditions should be taken into consideration with a holistic approach in the conservation process of municipal markets.
\end{abstract}

Keywords Municipal Market, Culture, Conservation, Adaptive Reuse Strategies, Sustainability, Cyprus

\section{Introduction}

Municipal markets, which usually represent the oldest shopping facilities for a district, are mostly located in the historic centre of the city. They represent the living style, cultural identity and the socio-cultural values of the related society. In this respect, municipal markets should be conserved and reused for the continuity of these values. They should be restored not only for the local community; but they have potential to be become important tourist attractions of the city and contribute to economy. All around the world, tourists visit traditional markets to experience the local culture, eat local food and buy traditional art and crafts [1].

According to Weiss [2], traditional marketplaces are 'a city within a city, with its own economy and a way of life'. They are not only places where trading occurs, but also a sense of community is usually built between the market vendors and the customers [3]. This kind of interaction between stakeholders creates a sense of place and this is one of the most important reasons to preserve these markets. Understanding their needs, experiences and memories of the users regarding to the place is one of the most important aspects that contribute to the sustainability [4].

In different countries they can be named different such as: traditional market, bazaar or municipal market. In Cyprus, they are called municipal market or locally called "bandabuliya". Unfortunately, there are not enough studies 
in the literature regarding with the conservation and sustainable adaptation of municipal markets. The main goal of the research is to fill the research gap and to raise the awareness in the issue.

The aim of the study is to highlight the significance of the traditional markets and examine the today's use of them. The research focuses on the municipal markets in Cyprus. Municipal markets located in the Northern and Southern part of the island is identified and observation through site survey is done to discover today's use and condition of the municipal markets. Also, sustainable adaptive reuse strategies are proposed for municipal markets in Cyprus.

\section{Literature Review}

Traditional market places are unique when compared with shopping malls and supermarkets since they reflect the local residents' life-style, habits and cultural identity, which make them more valuable [5]. Conservation of local urban marketplace is crucial in terms of preserving the heritage values. They play an important role as a place for commercial and cultural interchange [6]. The development of traditional markets is essential in the growth of the urban economy and in strengthening the sense of place of the city [7]. Traditional markets have played an important role in social, cultural and economic activities of the communities and contributed to the development of cities, architecture and a sense of place. Traditional markets can be seen as a symbol of tradition and as part of a city's tangible and intangible heritage [8].

Traditional markets should be preserved and sustained as an important component to conserve collective memory. The factors affecting the sustainability of a traditional marketplace can be divided into ten categories as government involvement, marketing strategy, market management, physical qualities of the traditional marketplace, the condition of the product being sold in the traditional marketplace, traditional marketplace consumer behavior and demand, locational attributes, price of the product, the vendor's behavior and other influencing category [9]. All these aspects should be taken into consideration with a holistic approach for achieving sustainable use of traditional marketplaces.

The model represents the important aspects that should be taken into consideration in the decision-making process of developing sustainable adaptive reuse strategies for municipal markets. The first step should be the identification of physical characteristics and the authenticity of the traditional market places that should be preserved. Necessary interventions should be aims preserving authenticity of the heritage and should follow contemporary conservation principles. Secondly, preserving also the socio-cultural values is important in terms of sustaining the traditional markets. Local people have place attachment to the traditional marketplace. In this respect, social meaning and the spirit of the place are crucial for the conservation of the marketplace.

Thirdly, the traditional marketplaces should also be economically sustainable as well for a successful reuse. For an economically sustainable traditional marketplace, population density, and market opportunity in the location and economic growth in the region are the factors that should be taken into consideration. Additionally, local visitor, cultural heritage tourism potential and the public interest need to be considered for the profits of future maintenance cost (Figure 1).

Then, after the analysis of the traditional market in terms of physical, social and economic aspects, two adaptation possibilities should be investigated in terms of advantages and disadvantages for the future use of the traditional market; however, the needs of the district and economic aspects should also be taken into account in the decision-making process.

Before the final decision, advantages and disadvantages of the discussed adaptation possibilities should be investigated. The policy and ownership issues should also be taken into consideration in the decision-making process. As the final step a management plan of the market should be prepared for the economic sustainability of the traditional markets [1].

The proposed model can be used with consultative and collaborative decision-making approaches. In a consultative approach an expert could be hired as an advisor and inform the actors about the results, but the final decision depends on the actors. On the other hand, in the collaborative approach, decision makers and actors meet together discuss the alternatives strategies [1].

The model proposes a holistic approach and it can be applied to any traditional marketplace in any circumstance. The main goal of the model is to assist professionals in the decision-making process in developing sustainable adaptive reuse strategies for municipal markets. 


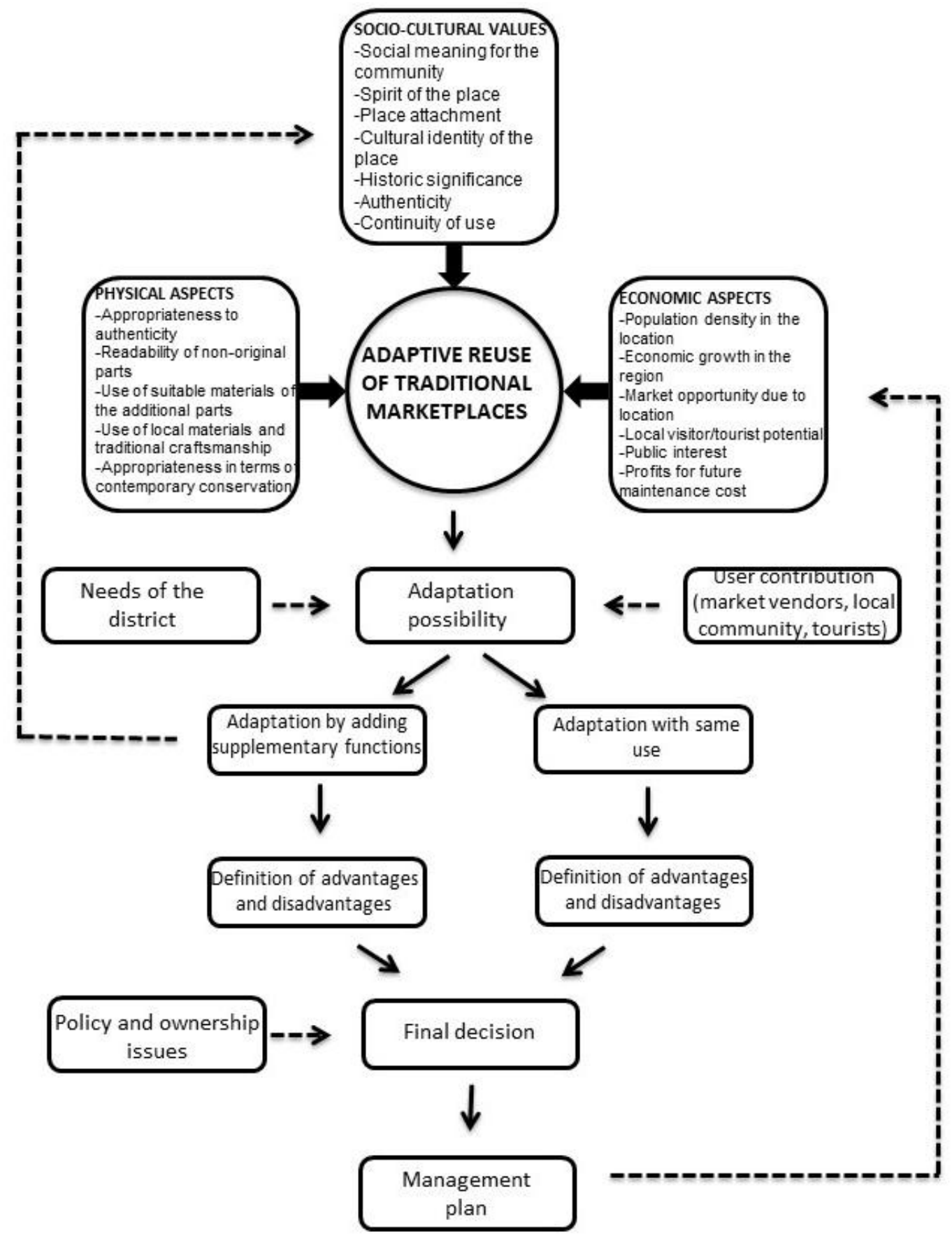

Figure 1. The model for achieving sustainable adaptive reuse of traditional marketplaces [1]

\section{Research Methodology}

The research method consists of three main parts. First, literature is surveyed for identifying the municipal markets in Cyprus including Northern and Southern part. Secondly, observation through site survey was completed in order to discover today's use and condition of the municipal markets. Also, the transformation of municipal markets in Cyprus is discussed within the scope of the study. Lastly, "the model for achieving sustainable adaptive reuse of traditional marketplaces" is used to develop sustainable adaptive reuse strategies for municipal markets in Cyprus.

\subsection{Literature Survey}

As the method of the study, first, literature survey is conducted for identifying the number and location of municipal markets in Cyprus including Northern and Southern part. Also, relevant research studies have been analysed in order to discover adaptive reuse approaches of municipal markets.

\subsection{Observations through Site Survey}

Municipal markets have been observed through site survey, which are located in different parts of Cyprus. Then, 
they have been investigated in terms of today's use, physical condition and the context that they are located. Also, the transformation of municipal markets in different periods has been examined.

\subsection{Developing Proposals for Sustainable Municipal Markets}

Lastly, a model entitled "the model for achieving sustainable adaptive reuse of traditional marketplaces" is used to develop sustainable adaptive reuse strategies for municipal markets in Cyprus. The model proposes basic considerations that must be taken into account in the decision-making process of traditional market places. Within the scope of the study, the model for achieving sustainable adaptive reuse of traditional marketplaces is used and the proposed steps are followed to develop sustainable adaptive reuse strategies for municipal markets located in Cyprus.

\section{Significance of Municipal Markets as Cultural Heritage}

Municipal markets are important in terms of understanding Cyprus culture. Municipal market culture in Cyprus, which is locally called "Bandabuliya", dates back to Ottoman period. On the other hand, today's condition of the market buildings mostly built in British colonial period on the island. Municipal markets were not only places for trade but also a place for gathering, meeting and socializing place among people.

Municipal markets have a significant impact on urban culture not only economically but also socially, culturally and politically. Marketplace or bazaar culture dates back to $18^{\text {th }}$ century in Cyprus. Bazaar, covered market or bedesten, which were typical in Turkish-Islamic architecture, established for trade purposes and they usually located next to the main mosque of the city [10].

Products from surrounding villages of the island were loaded onto donkeys or carts, and, later, in trucks and had brought to the city centers to be sold in the municipal markets. Since the supermarkets were not introduced to the cities in these days, they were the places where the city residents purchased all their daily supplies.

Establishment of municipal markets had economic benefits to the cities. It is stated by M. Necati Özkan that the establishment of Nicosia Bandabuliya, which was the first municipal market in Nicosia and built in 1932, had following economic benefits [10]:

- Bandabulya had become the shopping center for the people of Nicosia, as well as the people coming from villages and towns.
The income of craftsmen increased substantially.

Tradesmen started to get a share from prisons, hospitals, police and military appointments.

- The empty shops in the surrounding area were rented and started to generate good income.

- The number of customers and incomes of the shops, restaurants, coffee houses and other workplaces around the Municipality Bazaar were increased.

- Real estate and district were honored and valued. Later, with investments concentrated in this region, the segment has become a market center.

- The district had such a building that was realized as a result of a great investment.

When the municipal markets in analyzed in terms of typology, it is seen that they have different characteristics. On the other hand, the content was similar in all municipal markets located on the island. Today, due to the transformation and changes in the life style, municipal markets lost their significance in 1980s due to several reasons. Changes in the social and economic structure and market demands, transformed municipal markets to different structure [11].

Unfortunately, municipal markets lost their identity and significance. There are still some municipal markets where vegetable and fruit sales continue, but they have taken a different structure and have moved away from the traditional market place understanding.

\section{Critical Discussions on the Municipal Markets in Cyprus}

Cyprus is a divided island with a buffer zone. In 1974, the island is divided into the as Northern and Southern part. As a consequence, Turkish Cypriots started to live on the North and Greek Cypriots on the Southern part of the island. Some of the municipal markets were built before the division, in which two communities were living together. However, some of them were built after the division since municipal markets remained in different parts of the island.

According to the observations through site survey, totally 11 municipal market has been identified. Three of them are located in Nicosia, two in Limassol, and the rest is located in Paphos, Girne, Mağusa, Güzelyurt, Lefke and Yeniiskele.

Totally, there are three municipal markets in Nicosia. The one in the North is the oldest municipal market in Nicosia built in 1932 during the British period. The second one is built after the division of the island in 1974. The third one is originally built as a town hall and reused as the municipal market after the move of the town hall (Figure 2). 


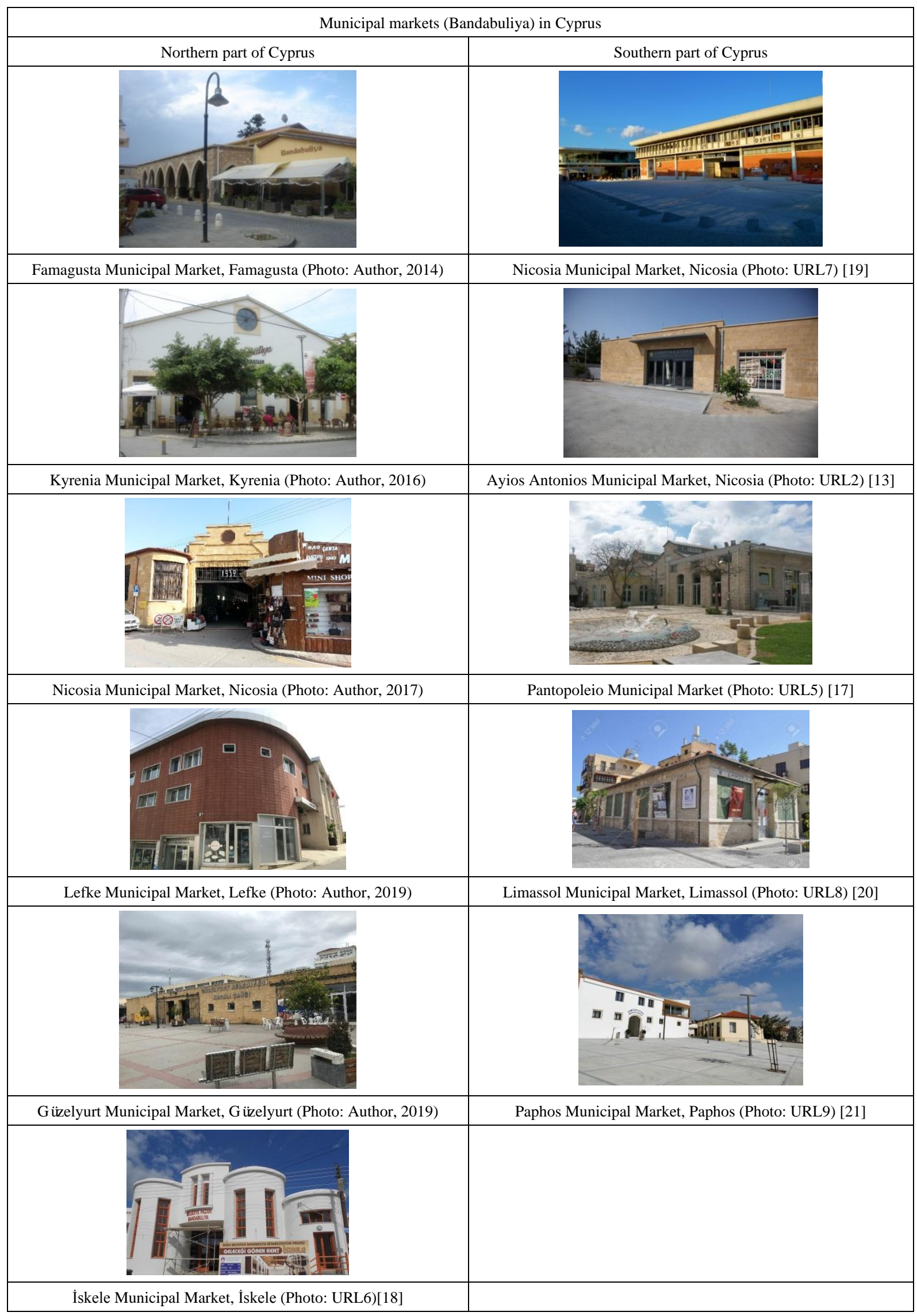

Figure 2. Municipal markets (bandabuliya) in Cyprus 
The municipal market in Northern part of Nicosia was constructed in 1932. Also, it is known that there was an open-air bazaar in the place of municipal market today in the $19^{\text {th }}$ century and it is covered in 1932 [10]. The old market is composed of two sections: a wholesalers and a retailer's part. The conservation works of the market started in 2004 when United Nations Development Programme- Partnership for Future (UNDP-PFF) rehabilitated the old wholesalers' section to be a recreation space with bars, a café and a restaurant [12].

The Ayios Antonios Municipal Market building in Nicosia is built as Town Hall and then converted to municipal market. When the municipal authorities moved to the modern Town Hall, the area became the city's main municipal market. It is a place where farmers and producers from the entire district gather here to sell fresh fruit and vegetables [13]. The renovation and expansion of the Ayios Antonios Municipal Market has been completed and the market is now at a new, well modernized and upgraded building.

The Old Municipality Market was built in walled city of Nicosia in 1967. It is a very important landmark building and a pure sample of the Modernism Architecture in Cyprus, designed by the known modernist architect $\mathrm{S}$. Oikonomou. It was built after division of the walled city of Nicosia in 1974, as the original municipal market was located in the north part of the island. The municipal market building is undergoing restoration to be converted into a research center [14].

In Famagusta, the traditional market is located in the city centre next to Lala Mustafa Pasha Mosque (former St. Nicholas Cathedral), the most important monument of the city. There is no exact construction date but it is known that the market dates back to Venetian times and it includes different additions at different times. According to analysis done by United Nations Development ProgrammePartnership for Future (UNDP-PFF), the current state of the building has been in existence since 1952. The building was the centre of commerce during Ottoman and British times, but fell into disrepair in the 1980s. However, with the help of the UN Development Programme in 2000, it has been restored and was re-opened in 2005 [15]. Today it has been converted to a multi-functional centre including cafes, restaurants, a bar and souvenir shops. The building has three entrances and there are shops around the inner courtyard. Today, it is used by Eastern Mediterranean University, faculty of architecture for studio courses (Table 1).

The Kyrenia traditional market was originally constructed during the British Colonial Period, which was used as a city hall, and had an outdoor market adjacent. In
2005, the building was renovated and reused as a market, tourism and craft centre with dining and drinking [15]. Although, the buildings are restored and brought back to life, it is not taking enough attraction as it deserves.

Lefke municipal market is renovated in 2017 and reused as multi-purpose hall. Unfortunately, today the heritage building is used as a closed parking place.

İskele Bandabuliya is renovated between 2014 and 2018. The renovation project proposes the municipal market to be used as a multi-functional center that includes a restaurant where local dishes is served, a cafeteria where local desserts is served, 12 shops where products and handicrafts produced in the region is sold, a city information office, exhibition halls and central courtyard. The project aimed to make municipal market a meeting point of local actors, the public and foreign guests; however, the building is preserved but municipal market is disused now.

Paphos Municipal Market is divided into two areas, the indoor and the outdoor areas. Local arts and crafts like lace tablecloths, artwork and homemade delicacies are sold. Also, fresh food, vegetables, fish and meat can be bought in the market. The Paphos market is one of the sustainable municipal markets in Cyprus, since physical, economic and socio-cultural aspects of the market are sustained.

'Pantopoleio' Municipal Market is the first municipal market of Limassol that was built in 1918 during British period of the island. It was expanded to include housing in 1932 and its expansion was completed in 1948 when it reached its current form. However, the market had lost its attraction at the end of the 20th century, due to the abandonment of the historical center. The expansion of Limassol city to the new development areas and the introduction of modern department stores caused a change in peoples' lifestyles. As a result, the market was no longer as popular as it once was [16]. Limassol's municipal market is renovated in 2019 to give a new life into the area and attract local and foreign visitors. The current use of the municipal market supported as functions such as wholesale and retail outlets, restaurants and cafes, children's recreation areas, conference rooms and offices. The aim of the conversion was to combine traditional and commercial uses such as the sale of traditional products and handicrafts, recreation, catering and cultural events [16]. The contract for the management of the municipal market will be valid for a period of 10 years and can be renewed for another five years. The investor will undertake the renovation and management of all premises [17].

Table 1 is prepared to examine municipal markets in terms of location, physical condition, material and structure system and current use. 
Table 1. General information of municipal markets (bandabuliya) in Cyprus (Developed by Author)

\begin{tabular}{|c|c|c|c|c|c|}
\hline \multicolumn{6}{|c|}{ MUNICIPAL MARKETS (BANDABULIYA) IN CYPRUS } \\
\hline NAME & LOCATION & $\begin{array}{c}\text { CONSTRUCTION } \\
\text { PERIOD }\end{array}$ & $\begin{array}{l}\text { PHYSICAL } \\
\text { CONDITION }\end{array}$ & $\begin{array}{c}\text { STRUCTURE } \\
\text { SYSTEM AND } \\
\text { MATERIAL }\end{array}$ & $\begin{array}{l}\text { CURRENT } \\
\text { USE }\end{array}$ \\
\hline $\begin{array}{c}\text { Famagusta Municipal } \\
\text { Market }\end{array}$ & $\begin{array}{c}\text { Famagusta, } \\
\text { Northern Cyprus }\end{array}$ & British colonial period & Renovated & Masonry, sand stone & $\begin{array}{c}\text { Multifunctional } \\
\text { center }\end{array}$ \\
\hline $\begin{array}{c}\text { Nicosia Municipal } \\
\text { Market }\end{array}$ & $\begin{array}{c}\text { Nicosia, Northern } \\
\text { Cyprus }\end{array}$ & British colonial period & Renovated & Masonry, sand stone & $\begin{array}{c}\text { Municipal } \\
\text { market }\end{array}$ \\
\hline $\begin{array}{c}\text { Kyrenia Municipal } \\
\text { Market }\end{array}$ & $\begin{array}{c}\text { Kyrenia, Northern } \\
\text { Cyprus }\end{array}$ & British colonial period & Renovated & Masonry, sand stone & $\begin{array}{c}\text { Multifunctional } \\
\text { center }\end{array}$ \\
\hline $\begin{array}{c}\text { Güzelyurt Municipal } \\
\text { Market }\end{array}$ & $\begin{array}{c}\text { Güzelyurt, } \\
\text { Northern Cyprus }\end{array}$ & After 1974 & Renovated & Masonry, sand stone & $\begin{array}{c}\text { Municipal } \\
\text { market }\end{array}$ \\
\hline $\begin{array}{c}\text { Lefke Municipal } \\
\text { Market }\end{array}$ & $\begin{array}{l}\text { Lefke, Northern } \\
\text { Cyprus }\end{array}$ & After 1974 & Renovated & $\begin{array}{c}\text { Frame, reinforced } \\
\text { concrete }\end{array}$ & $\begin{array}{c}\text { No any active } \\
\text { use }\end{array}$ \\
\hline $\begin{array}{c}\text { İskele Municipal } \\
\text { Market }\end{array}$ & $\begin{array}{c}\text { İskele, Northern } \\
\text { Cyprus }\end{array}$ & After 1974 & Renovated & $\begin{array}{c}\text { Frame, reinforced } \\
\text { concrete }\end{array}$ & $\begin{array}{c}\text { Multifunctional } \\
\text { center }\end{array}$ \\
\hline $\begin{array}{l}\text { Nicosia Municipal } \\
\text { Market }\end{array}$ & $\begin{array}{c}\text { Nicosia, Southern } \\
\text { Cyprus }\end{array}$ & After 1974 & $\begin{array}{l}\text { On-going } \\
\text { Renovations }\end{array}$ & $\begin{array}{l}\text { Frame, Reinforced } \\
\text { concrete }\end{array}$ & $\begin{array}{c}\text { will be } \\
\text { converted to a } \\
\text { research center }\end{array}$ \\
\hline $\begin{array}{c}\text { Ayios Antonios } \\
\text { Municipal Market }\end{array}$ & $\begin{array}{c}\text { Nicosia, Southern } \\
\text { Cyprus }\end{array}$ & After 1974 & Renovated & Masonry, sand stone & $\begin{array}{c}\text { Municipal } \\
\text { market }\end{array}$ \\
\hline $\begin{array}{c}\text { Pantopoleio Municipal } \\
\text { Market }\end{array}$ & $\begin{array}{c}\text { Limassol, Southern } \\
\text { Cyprus }\end{array}$ & British colonial period & Renovated & Masonry, sand stone & Mixed use \\
\hline $\begin{array}{c}\text { Limassol Municipal } \\
\text { Market }\end{array}$ & $\begin{array}{c}\text { Limassol, Southern } \\
\text { Cyprus }\end{array}$ & British colonial period & Renovated & Masonry, sand stone & $\begin{array}{c}\text { No any active } \\
\text { use }\end{array}$ \\
\hline $\begin{array}{c}\text { Paphos Municipal } \\
\text { Market }\end{array}$ & $\begin{array}{c}\text { Paphos, Southern } \\
\text { Cyprus }\end{array}$ & British colonial period & Renovated & $\begin{array}{l}\text { Frame, Reinforced } \\
\text { concrete }\end{array}$ & $\begin{array}{l}\text { Municipal } \\
\text { market }\end{array}$ \\
\hline
\end{tabular}

\section{Conservation and Adaptive Reuse Strategies for Municipal Markets in Cyprus}

Due to the transformation and changes in the life style, municipal markets lost their significance in 1980s due to several reasons. Changes in the social and economic structure and market demand, transformed municipal markets to different structure.

Unfortunately, municipal markets lost their identity and significance. There are still some municipal markets where vegetable and fruit sales continue, but they have taken a different structure and have moved away from the traditional market place understanding.

Through analysis, it is achieved that most of the municipal markets lack a living function. In this respect, the new use approaches should be rethought within the context of sustainability. For the continuity of the heritage, municipal markets need to be socially, culturally and economically sustainable.

It should be accepted that it is not possible any more to use the municipal markets with the same approach they build. We need to adapt them to todays' needs by conserving their authenticity.

Municipal markets located in Cyprus have different typology: plan layout, façade characteristics and context. In this respect, different scenarios should be developed for each of them. It is also achieved that the municipal markets, which is built before the division of the island in 1974, build with masonry structure system; however, for the ones that constructed after the division of the island, reinforced concrete system is used.

It is observed through site surveys that, all municipal markets renovated and preserved. The biggest issue is the new use of the municipal markets and its sustainability. Although new uses were proposed for some of them, due to the decrease in the number of the visitors, municipal markets could not be sustained.

After the conversion of the heritage buildings, they need to be monitored in different time intervals by the ownership authorities. The aim of the monitoring should be to observe the heritage to see if there is an inappropriate use, change or addition that can be a threat to the heritage. Mostly, the ownership of these markets belongs to municipality, which they are busy organizations with other missions as well. Also, there is a lack of experts in the municipalities to handle these monitoring. In the example of Pantopoleio Municipal Market, the market hired to a private investor and a management contract is signed to have all supervisions. The contract is signed for short intervals such as 5 or 10 years in order to observe the use of the market.

As proposed in "The model for achieving sustainable adaptive reuse of traditional marketplaces", there are three important user profiles for the municipal markets: market vendors, local community and tourists. User's participation in the decision process is crucial for developing appropriate decision-making for municipal markets. It is observed that, user participation is ignored in the decision-making process. 
In decision making process new functions to the municipal markets should not decide according to the tourist's expectation. Thus, this is a threat against the conservation of socio-cultural values of the heritage buildings. On the other hand, tourist expectations are not only limited to activities such as shopping, resting, eating and entertaining. They also visit the building as a monument and experience local culture [1].

According to the model, there are two adaptation possibilities that should be investigated in terms of advantages and disadvantages for the future use of the municipal market. Also, the needs of the district and economic aspects should also be taken into account in the decision-making process. The first adaptation possibility is either use the marketplace with the same use with some necessary changes. On the other hand, the second option is reusing the marketplace by adding supplementary functions. These supplementary functions can support economy and also, can answer the needs and expectations of the visitors. When the approaches for the case studies is analysed, it is observed that using the marketplace with the same use will not be sustainable since due to the changes in the life style, municipal markets lost their significance. However, the third option, which is the changing the use of the market place totally and reusing with a different function, will harm the authenticity of the traditional marketplaces.

As a result, the most appropriate approach in terms of sustainability criteria is to reusing the marketplace by adding supplementary functions that will contribute social and economical sustainability of the municipal market. The conservation process of the municipal markets should be taken into consideration with a holistic approach. Loss of relationships between sustainability, community and cultural heritage causes the loss of sense of place and identity. For the continuity of the heritage buildings, spirit of place and local culture should be preserved as well as physical characteristics of the building [1].

\section{Conclusions}

Municipal markets should be conserved by considering the tangible and intangible heritage values. Local needs, beliefs, practice and traditions should be taken into consideration in the conservation process of municipal markets. There is no heritage without communities; in this respect, community participation is important in the decision-making process.

There are three important user profiles for the municipal markets: market vendors, local community and tourists. New use of the municipal markets should satisfy three different user profiles.

Necessary interviews should be conducted in order to define the needs and the expectations of the market vendors, local community and tourists. Defining the stakeholders' views in the decision-making process contributes to proposing the most appropriate strategy for the heritage building. Similarly, public awareness must be increased in preserving socio-cultural values of the municipal markets.

In the re-functioning process of the municipal markets, new additions can be proposed to fit the market to the space requirements of the new use. However, new addition should be compatible with the heritage building but legible. The new additions should be differentiated from the old ones so that they can be removed anytime without harming the heritage building.

For the continuity of the municipal markets social, cultural and economic aspects should be taken into consideration holistically. Management plans should also be prepared by the experts in order to define management strategies for the economic sustainability of the municipal markets

\section{REFERENCES}

[1] Misirlisoy D. "Towards Sustainable adaptive reuse of Traditional Marketplaces" The Historic Environment: Policy and Practice, 2020. DOI: 1 0.1080/17567505.2020.1784671.

[2] Weiss W. The bazaar: Markets and merchants of the Islamic World, Thames and Hudson, 1998.

[3] Ryan C. Researching tourist satisfaction: Issues, concepts, problems, Routledge, 1994.

[4] Elsorady D. A. "Assessment of the compatibility of new uses for heritage buildings: The example of Alexandria National Museum, Alexandria, Egypt.” Journal of Cultural Heritage, vol.15, pp. 511-521, 2014.

[5] Stead V., Market crossings: Plotting a course through the Preston Market, Melbourne, Breakdown Press, 2010.

[6] UNESCO, 2013 "New life for historic cities" http://whc.unesco.org/. (accessed Jan 12. 2021)

[7] Ghapar M. H. A., Zakariya K., Harun N. Z. and Zen I. "Factors Influencing the Change in the Sense of Place of Markets in Urban Regeneration." Middle-East Journal of Scientific Research, vol. 24, no.2, pp. 353-358, 2016.

[8] Kalan A.M. and Oliveria E., The sustainable architecture of bazaars and its relation with social, cultural and economic components: Case study: the historic bazaar of Tabriz, International Journal of Architecture and Urban Development, vol. 5, no. 4, pp. 5-12, 2015.

[9] Rahadi R., Prabowo F. S. A. and Hapsariniaty A. W. Synthesis of traditional marketplace studies in Indonesia, International Academic Research Journal of Business and Technology, vol.1, no.2, pp. 8-15, 2015.

[10] Bağışkan, T. Tarihi Lefkoşa Belediye Bandabuliyası, (Historic Nicosia Municipal Market) Yenidüzen Gazetesi, 1 Ocak 2011

[11] İşcioğulları, D. Kıbrıs Kent Kültüründe Bandabulya, (Bandabulya in Turkish Cypriot Urban Culture) Milli Folklor, 
vol. 29, no.114, pp. 79-87, 2017.

[12] URL 1: http://www.cy.undp-pff.org (accessed in Feb. 12 2021).

[13] URL2:

https://www.nicosia.org.cy/en-GB/discover/markets/centralmunicipal-market/(accessed in Feb. 12 2021).

[14] Georgiou A., Ioannou I. and Pantazopoulou, S., Rehabilitation of 20th Century Concrete Heritage Buildings: the Case Study of the Municipal Market in Nicosia, Cyprus, Eartquake Risk and Engineering towards a resilient world, 9-10 September 2019, Greenwich, London, 2019.

[15] URL3: http://www.whatson-northcyprus.com (accessed Jan 1. 2021)

\section{[16] URL4:}

https://allaboutlimassol.com/en/photos-the-first-municipalmarket-a-center-of-life-and-commerce-for-more-than-a-cent ury (accessed in Feb. 12 2021).

[17] URL5:

https://in-cyprus.philenews.com/limassols-central-municipal -market-to-be-reborn/ (accessed in Feb. 12 2021).

[18] URL 6: https://www.iskelebelediyesi.com/projeler (accessed in Feb. 12 2021).

[19] URL7:

https://commons.wikimedia.org/wiki/File:New_Nicosia_Mu nicipal_Market_square_Nicosia_Cyprus_19.jpg (accessed in Feb. 12 2021).

[20] URL8:

https://www.123rf.com/photo_117571091_the-beautiful-old -building-municipal-market-limassol-in-cyprus.html (accessed in Feb. 12 2021).

[21] URL9:

https://www.paphospeople.com/paphos_town_(accessed in Feb. 12 2021). 